This PDF is a selection from a published volume from the National Bureau of Economic Research

Volume Title: Risk Topography: Systemic Risk and Macro Modeling

Volume Author/Editor: Markus Brunnermeier and Arvind Krishnamurthy, editors

Volume Publisher: University of Chicago Press

Volume ISBN: 0-226-07773-X (cloth); 978-0-226-07773-4 (cloth); 978-0-226-09264-5 (elSBN)

Volume URL: http://www.nber.org/books/brun11-1

Conference Date: April 28, 2011

Publication Date: August 2014

Chapter Title: Monitoring the Financial Condition and Expenditures of Households

Chapter Author(s): Robert E. Hall

Chapter URL: http://www.nber.org/chapters/c12550

Chapter pages in book: (p. 175 - 182) 


\title{
Monitoring the Financial Condition and Expenditures of Households
}

\author{
Robert E. Hall
}

- Household expenditure accounts for about two-thirds of GDP; it accounted for a large fraction of the decline in GDP following the financial crisis.

- Households went on a spending binge in the middle of the 2000s, building up unusually high stocks of housing, cars, and other durable assets, along with a large volume of debt to finance the spending.

- The crisis resulted in a large volume of household deleveraging - households contracted consumption to pay off debt.

- The United States has excellent data on many categories of expenditure, asset holdings, and debt, summed across all households, but much less information about the variation of these quantities across the range of poor-to-prosperous households.

- Existing data sources could be improved, by collecting data more often and by collecting data from panels of households.

- Online and administrative sources not currently tapped could add a great deal to information about household finances and expenditure.

Households purchase about two-thirds of the output of the US economy. Cutbacks in household expenditure are a factor in every recessionthe Great Recession starting at the end of 2007 was no exception. Because many households - arguably the majority — are dependent on financial insti-

Robert E. Hall is the Robert and Carole McNeil Joint Hoover Senior Fellow and Professor of Economics at Stanford University and a research associate and director of the Economic Fluctuations and Growth Program at the National Bureau of Economic Research.

For acknowledgments, sources of research support, and disclosure of the author's material financial relationships, if any, please see http://www.nber.org/chapters/c12550.ack. 
tutions for credit, events in financial markets have immediate and powerful effects on household expenditure and thus on output and employment.

Figure 12.1 shows household purchases of new houses and consumer goods and services since 2001 along with business purchases of plant and equipment and government purchases. Household purchases began sagging at the end of 2007, reached their minimum in 2009, and have grown slowly since then. They are still well below their growth path from 2001 to 2007. Business purchases dropped sharply after the financial crisis of late 2008 and rebounded back to almost their earlier growth path before falling again in the slowdown of 2011. The level of household purchases dwarfs the other two components at all times. I should note that household purchases as shown here exceed consumption expenditure in the National Income and Product Accounts because they include purchases of new houses, which the NIPAs count as investment.

It is useful to divide household expenditure into three categories as shown in figure 12.2: (a) new houses, (b) cars and other consumer durables, and (c) nondurable goods and services. The third category is by far the largest,

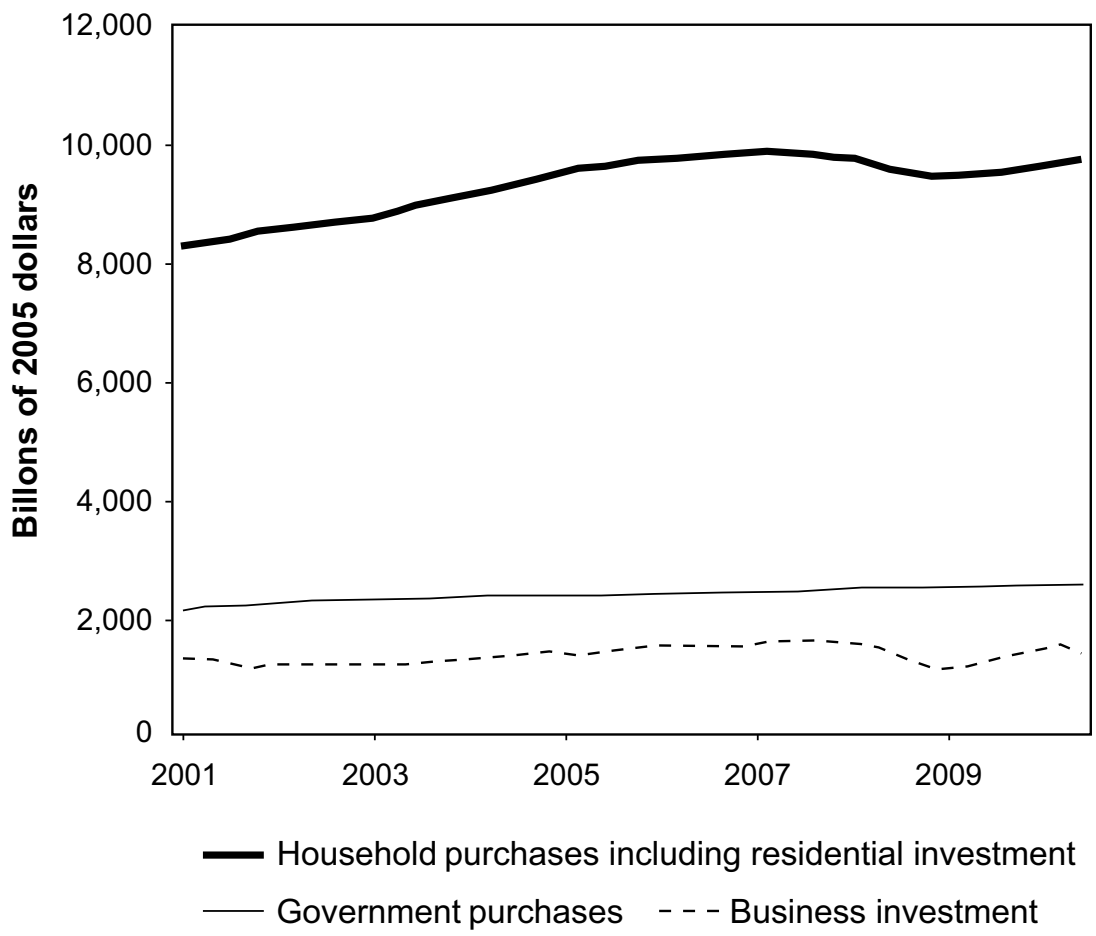

Fig. 12.1 Household purchases dominate the level and movements of output 


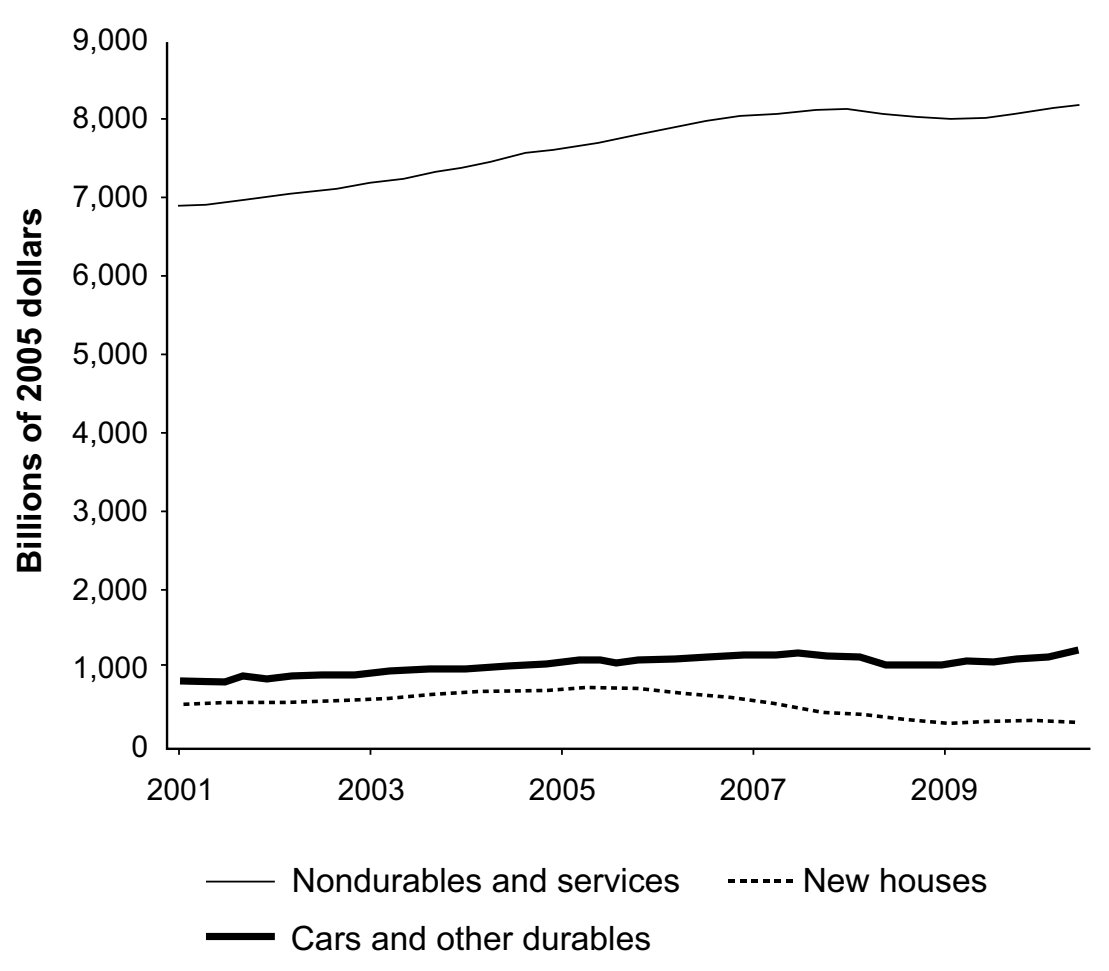

Fig. 12.2 Components of household purchases

but the first two are more volatile and more sensitive to financial events because most families borrow to buy houses and cars.

Macroeconomists are close to a consensus about the origins and mechanisms of the Great Recession. In the middle years of the decade, households were on a borrowing and buying binge. Figure 12.3 shows that household stocks of housing and durables reached an unusual level relative to the gross domestic product (GDP) in the second half of the decade. Although some economists have concluded that easy money and plentiful credit in general accounted for the binge, as figure 12.3 also shows, no similar binge occurred in business holdings of plant and equipment. Forces specific to households, including the expansion of subprime mortgages and the expectation of rising house prices, appear to be the main proximate causes.

Households took on large amounts of new debt to finance their binge purchases. Figure 12.4 shows that new borrowing considerably exceeded interest payments and repayment of principal until the middle of 2006. From 2002 to 2006, households played a Ponzi game. Then, in a sudden reversal, from 2007 to the present, households paid hundreds of billions of dollars back to lenders (net of debt forgiven on account of default). 


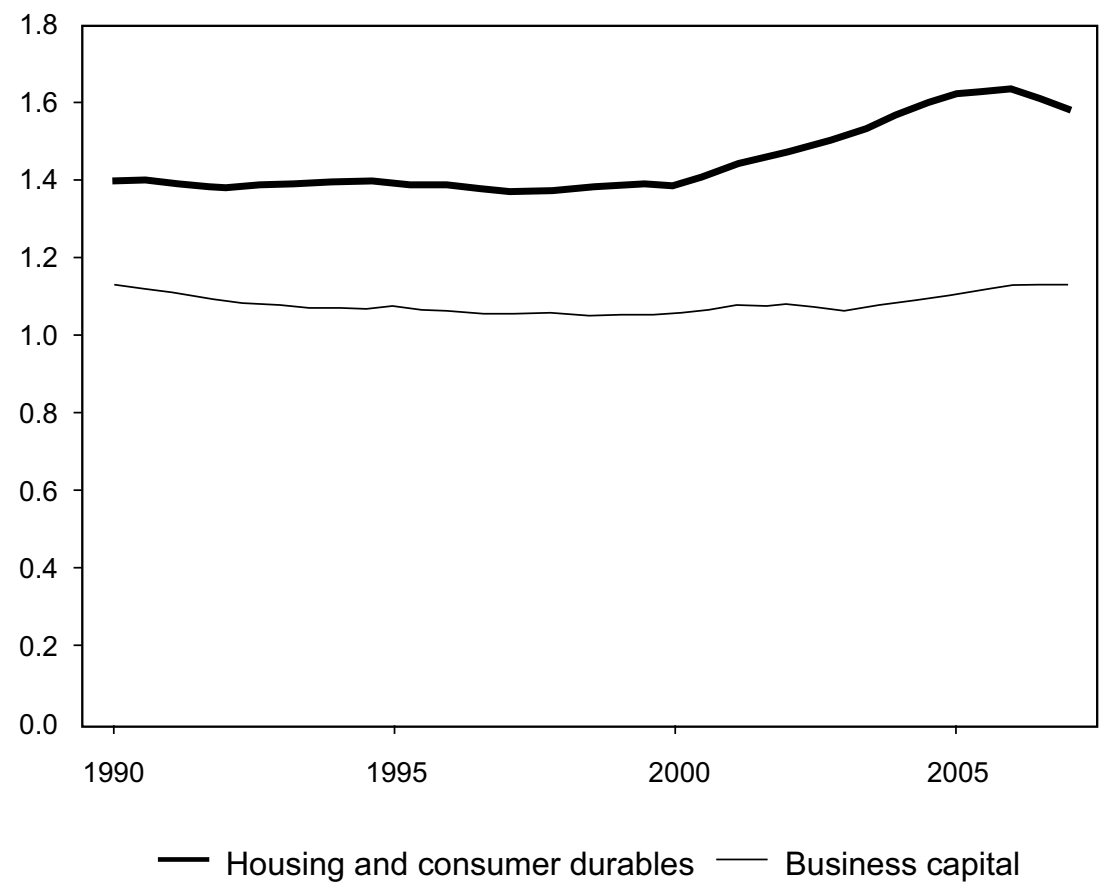

Fig. 12.3 Ratios of capital and durables to GDP

Why did the reversal of cash flows occur? In the first place, a Ponzi game cannot go on forever, so at some point households would have shifted to making positive net cash payments to lenders. But the financial crisis appears to have contributed to the speed and magnitude of the reversal. As house prices reached their maximum values in 2006 and started downward, banks and other financial institutions began to suffer depletion of capital. One response was to cut back dramatically in lending to households and other borrowers. Figure 12.5 shows indexes of lending standards inferred from the Senior Loan Office Survey of the Federal Reserve Board.

Finally, households faced a large and continuing increase in financial stress. Figure 12.6 shows one measure, an index of Google queries for "withdrawal penalty." The upsurge in consumer concern about penalties for accessing retirement plans and other forms of wealth confirms that many households were unable to borrow on normal terms from financial institutions.

Data aggregated over all US households are readily available in great detail for expenditures and financial positions. The major sources are as follows:

- The National Income and Product Accounts of the Bureau of Economic Analysis, Department of Commerce, contain detailed monthly 


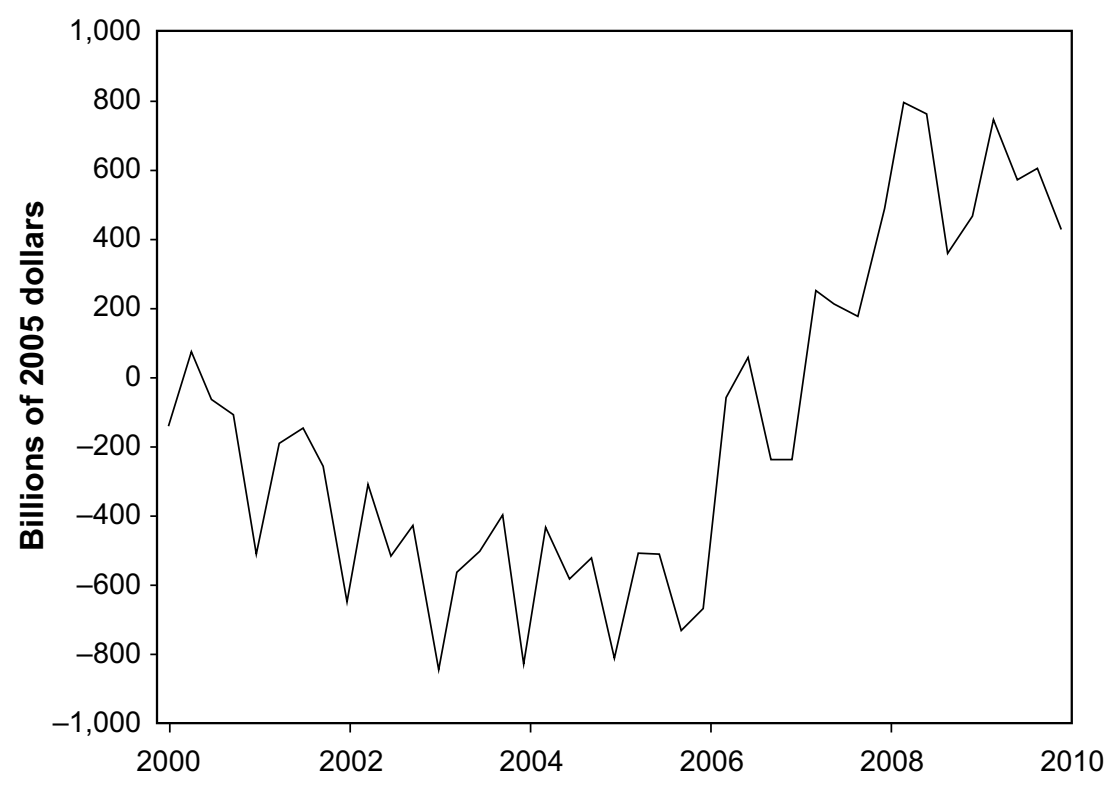

Fig. 12.4 Net cash flowing from households to lenders

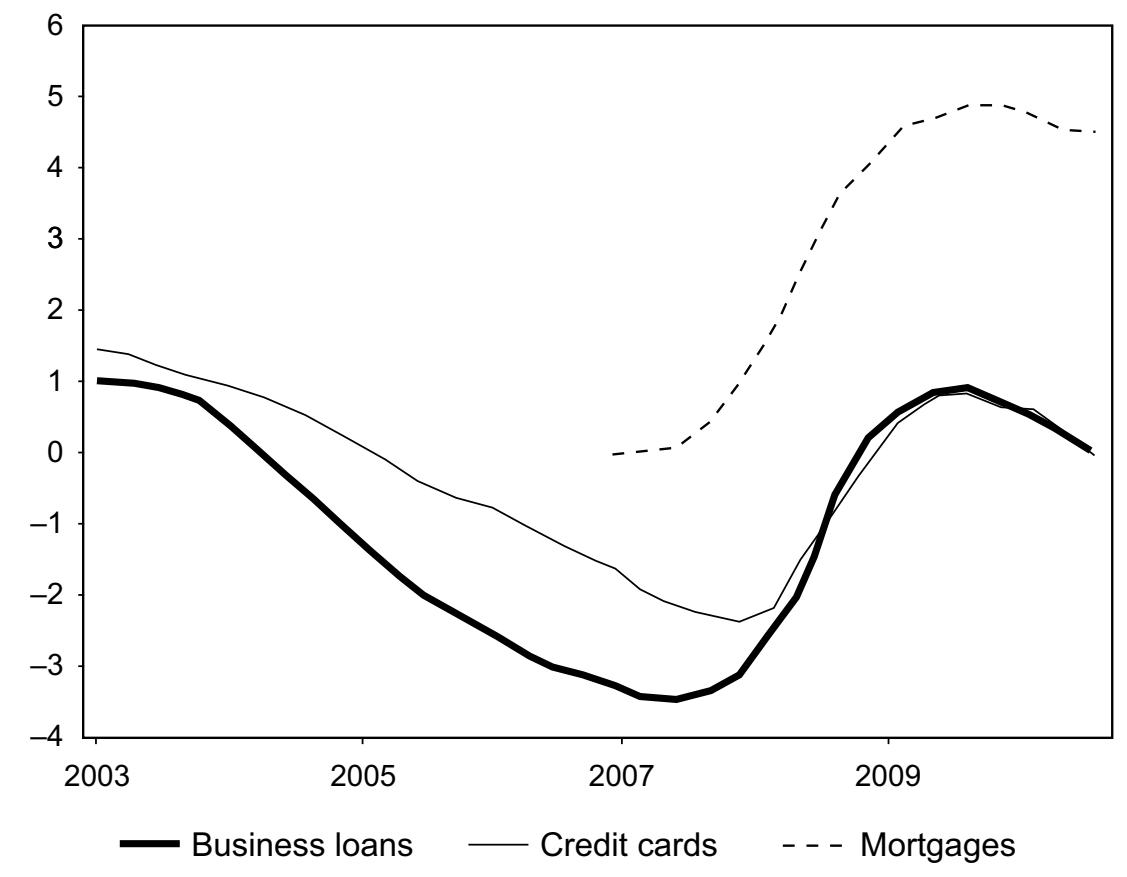

Fig. 12.5 Indexes of lending standards inferred from the FRB Senior Loan Officer Survey 


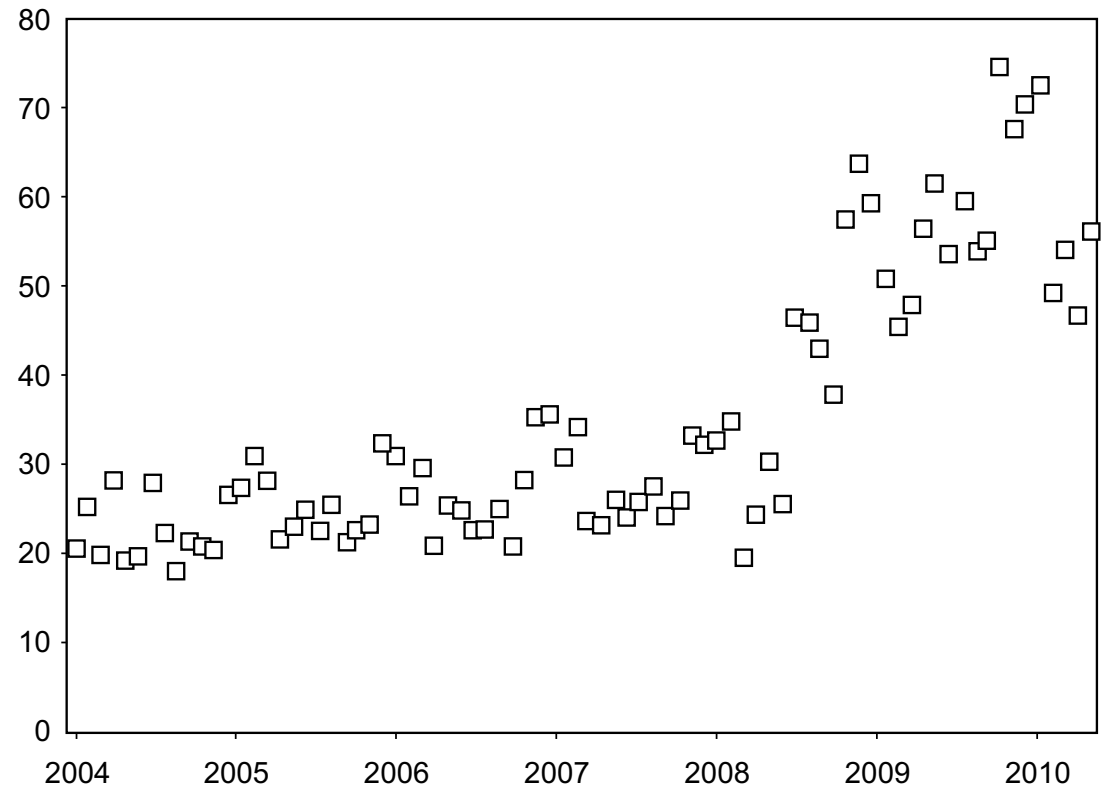

Fig. 12.6 Index of Google queries for "withdrawal penalty"

data on personal and disposable income and on expenditures in detailed categories, together with their prices. The satellite Fixed Asset Accounts report stocks of housing and consumer durables.

- The Flow of Funds Accounts of the Federal Reserve Board contain detailed balance sheets for US households.

- The Federal Reserve Board publishes data on interest rates and chargeoff rates for a variety of types of consumer debt.

- The Bureau of Labor Statistics, Department of Labor, and the Department of the Census conduct the Current Population Survey, which provides monthly estimates of employment, unemployment, and related measures of household involvement in the labor market.

The aggregate data sources are inadequate for the task of monitoring household financial positions and expenditure levels, because they conceal vast heterogeneity among US households. In particular, holdings of financial wealth are extremely skewed. More than half of US families hold less than $\$ 10,000$ in financial wealth apart from retirement funds, yet total wealth is hundreds of thousands of dollars per family. Table 12.1 shows aggregate financial assets and liabilities of US households, as dollars per household, in late 2011, from the Flow of Funds data. On average, American households hold substantial financial assets, well in excess of their borrowing. But the average conceals the fact that the majority of households hold no 
Financial assets and liabilities of US households, thousands of dollars per household, third quarter, 2011

\begin{tabular}{cc}
\hline & Thousands of dollars \\
\hline Financial assets & 418 \\
Deposits and stocks & 175 \\
Other assets & 244 \\
Liabilities & 121 \\
Mortgages & 87 \\
Consumer credit & 22 \\
\hline
\end{tabular}

financial assets to speak of. Moreover, these are the households who owe all of the consumer debt and much of the mortgage debt. See Kaplan and Violante (2011) for a discussion of the role of illiquid high-debt households, who include many with quite high incomes. The aggregate data fail to completely convey the reality among American families, most of whom are financially precarious. They deal with adverse shocks by cutting back consumption expenditures, especially cars and other durables, rather than by drawing down liquid savings. In times when consumer credit is plentiful, these families maintain consumption by running up credit card balances, but this habit makes their expenditure sensitive to credit tightening, as occurred during the financial crisis. For a theoretical model that gives a full treatment to the range of experiences among households depending on their liquidasset positions, and to their response to credit tightening, see Guerrieri and Lorenzoni (2011).

Existing sources of data at the household level include the following:

- The Bureau of Labor Statistics's Consumer Expenditure Survey measures consumption at the family level but does not follow families over much time. Its aggregates over products disagree substantially with NIPA. The BLS is working on improving the survey. See Attanasio, Hurst, and Pistaferri (2012) for recent work on correcting the errors in the survey.

- The Panel Study of Income Dynamics measures consumption of a sample of families every two years. See Dynan (2012) for a study of the differences among consumer behavior during the crisis based on their immediate precrisis debt holdings, using PSID data.

- The Federal Reserve Board's Survey of Consumer Finances measures family assets and liabilities in great detail — every three years — but does not usually follow families over time. The Fed conducted a special resurvey of the 2007 respondents in 2009 to track the effects of the financial crisis and Great Recession.

One improvement in the value of household data would involve conducting the Survey of Consumer Finances annually and including families in it for two or more years. The 2009 resurvey demonstrated the practicality of 
gathering information a second time from the same respondents. The design of the resurvey carefully considered the burden on the respondents and avoided repeating many of the questions from the original survey.

A more ambitious and controversial approach would collect financial and flow data from families from administrative and financial institution records. This approach would blend data from the Internal Revenue Service and all financial institutions, linked by Social Security numbers. With reliable income and wealth data, expenditure could be measured as income less the increase in wealth. Jonathan Parker's chapter 13 in this volume explores the possibilities of comprehensive household data collected from administrative and other records.

Amir Sufi and Atif Mian have demonstrated the benefits of an intermediate level of data, from detailed geographic data. See, in particular, Mian and Sufi (2012). Sufi's chapter 14 in this volume pursues the idea of tracking dangerous expansions in household credit resulting from the easing of lending standards, using data at the zip code level.

\section{References}

Attanasio, Orazio, Erik Hurst, and Luigi Pistaferri. 2012. "The Evolution of Income, Consumption, and Leisure Inequality in the US, 1980-2010." NBER Working Paper no. 17982, Cambridge, MA.

Dynan, Karen. 2012. "Is a Household Debt Overhang Holding Back Consumption?" Brookings Papers on Economic Activity 44 (1): 299-362.

Guerrieri, Veronica, and Guido Lorenzoni. 2011. "Credit Crises, Precautionary Savings and the Liquidity Trap." NBER Working Paper no. 17583, Cambridge, MA.

Kaplan, Greg, and Giovanni L. Violante. 2011. "A Model of the Consumption Response to Fiscal Stimulus Payments." Unpublished Manuscript. Princeton University.

Mian, Atif, and Amir Sufi. 2012. "What Explains High Unemployment? The Aggregate Demand Channel." Chicago Booth Research Paper no. 13-43 (November). University of Chicago, Booth School of Business. 